\title{
Empirical Evaluation Indicators in Thai Higher Education: Theory-Based Multidimensional Learners' Assessment
}

\author{
Dawisa Sritanyarat \\ Administration, Bangkok, Thailand, dawisa.s@gmail.com \\ Darlene Russ-Eft \\ College of Education, Oregon State University, Corvallis, OR, USA, \\ darlene.russeft@oregonstate.edu
}

Graduate School of Human Resource Development, National Institute of Development

This study proposed empirical indicators which can be validated and adopted in higher education institutions to evaluate quality of teaching and learning, and to serve as an evaluation criteria for human resource management and development of higher institutions in Thailand. The main purpose of this study was to develop empirical indicators of a theoretically-based multidimensional learners' evaluation in Thai higher education adopting the National Institute of Development Administration as a case study. Research method of this study was developed based on Dubin's Theory Building Model. Units, which are basic building blocks of newly developed concept, were developed qualitatively and quantitatively by triangulating data obtained from the systematic literature review, the qualitative data collection, and the Likert-scale survey. Patterson's (in Holton and Lowe, 2007) criterion was used to evaluate the conceptual framework. Questionnaire was used as a tool for data collection. Exploratory factor analysis and Cronbach's alpha analysis were used to analyse the collected data in order to develop empirical indicators.

Key Words: learners' evaluation, higher education, Thailand, Dubin, theory building

\section{INTRODUCTION}

Higher education institutions have adopted several approaches and methods for quality improvement and evaluation as higher education institutions around the world have to respond to greater accountability and quality assurance (Hendry \& Dean, 2002). In higher education setting, student evaluation or learners' reaction has been studied since the 1920's. The utility of learners' reaction in formative and summative evaluation has been continuously confirmed by researchers (Wachtel, 1998). Student evaluation of teaching is an integral part of higher education practice (Shevlin et al., 2000). Despite the fact that student evaluation of teaching has been widely used, there have been theoretical issues that have not resolved yet, for example, dimensions to be covered in the evaluation (Shevlin et al., 2000). 
According to the Office of Higher Education Commission of Thailand (OHEC), the evaluation of higher education quality is undertaken to help ensure the quality of the higher education institutions. The evaluation covers administrative systems and the mechanism of teaching and learning (Office of the Higher Education Commission, 2007). Learners' evaluation is counted as a part of indicators in the area of teaching and learning. Under the supervision of the OHEC, the National Institute of Development Administration (NIDA) continues to perform evaluation of educational quality using learners' evaluation.

The results of the evaluation are used for the purposes of identifying needed improvements in teaching and learning processes and those in human resource management actions, such as assessment of strengths and weaknesses of programs, identification of teaching technique and skill training for instructors, and development plans for instructors. Given its importance, the evaluation should be designed carefully in order to evaluate the quality of education properly and should yield valid results.

\section{LITERATURE REVIEW}

Sritanyarat (2014) developed a theory-based conceptual framework of multidimensional learners' evaluation as an initial stage of developing teaching and learning quality evaluation tool for higher education. The study followed Dubin's theory building method from the first to the fifth step, which will be discussed shortly. The indigenous conceptual framework consists of 25 units of evaluation. To utilize this theory-based conceptual framework, the development of empirical indicators is needed to improve the measurement of the values of each unit (Dubin, 1969; Lynham, 2002).

This study takes on Sritanyarat's (2014) initial conceptual framework to complete the sixth step of Dubin's theory building method, namely empirical indicators development, with the purpose of providing higher education in Thailand, starting with NIDA, an evaluation tools for teaching and learning quality.

\section{Dubin's Theory-Building Method}

Dubin developed a widely-used theory building method (Holton \& Lowe, 2007), and this method received attention in the field of human resource development (HRD) (Holton \& Lowe, 2007). Dubin's hypothetical-deductive theory building model is necessary for developing a valid and trustworthy applied theory (Lynham, 2002), or knowledge construction (Holton \& Lowe, 2007; Lynham, 2002).

Dubin proposed two different but related components of theory building: the theory development, and the research operation (Lynham, 2002). Completion of the first component results in a conceptual framework of the theory. Completion of the second component results in the development of valid and trustworthy applied theory (Holton \& Lowe, 2007; Lynham, 2002). There are eight steps to complete these two components.

The following are eight steps Dubin (1983) proposed: 
i. Units are the basic building blocks, out of which the theory is built, or represent what the researcher is trying to make sense of (Dubin, 1983; Lynham, 2002). Units can also be referred to as variables (Dubin, 1983)

ii. Law of interaction represents the nature of the relationships among the units (Lynham, 2002)

iii. Boundaries determine and clarify the domains within the theory, where it is expected to hold up and apply (Lynham, 2002).

iv. System states tell about conditions under which the theory is operative as a system (Dubin, 1983; Lynham, 2002).

v. Propositions are specified to tell how a theory works in the real world (Lynham, 2002).

vi. Empirical indicators would be developed to secure the measurements of the values of the units (Dubin, 1969; Lynham, 2002). In other words, empirical indicators allow a theory to be tested.

vii. Hypotheses are developed with the goal of establishing the link between the theoretical framework and the real world, by translating some of the propositions of the theoretical framework to testable statements (Lynham, 2002).

viii. Testing is the last step which involves the testing of the theory through empirical research (Dubin, 1969).

Research methods for this study, similar to those of Sritanyarat (2014), were developed following Dubin's theory building model and Holton and Lowe's (2007) concept in performing Dubin's theory building model.

\section{The National Institute of Development Administration's Teaching and Learning Evaluation}

Currently, the evaluation using the learners' reaction-based evaluation is still a frequently-used method of learning evaluation (Yamnill, 2001) both in private and educational organizations, including NIDA. NIDA has established principles and methods for implementing the results of the teaching and learning evaluation of instructors to develop teaching and learning quality, and to develop instructors (National Institute of Development Administration. Personnel Department, 2012a).

At present, NIDA performs a learning based evaluation of teaching and learning quality to serve the purpose of education quality assessment and internal human resource management. The evaluation uses a faculty evaluation form (FEF), which is completed by students at the end of each semester. The results of this evaluation are used for developing course administration quality, identifying strengths and weaknesses of the programs, identifying training needs for instructors, and so on. This evaluation affects instructors' career as getting an evaluation rating lower than 3.51 can result in teaching suspension for instructors. Moreover, the evaluation results are included in promotion and salary increment consideration. 
The current faculty evaluation form of NIDA covers the evaluation of instruction effectiveness, the faculty's personal capability, and the use of teaching and learning media by the faculty. Considering all of the aspects of evaluation, it can be concluded that they cover only one dimension of learners' evaluation, which is the instructor-based evaluation. The uni-dimensional evaluation approach is different from what was suggested by Morgan and Casper (2000) that a multi-dimensional approach to learners' evaluation needs to be well designed in order to ensure the reliability.

The following are details of NIDA's faculty evaluation form, which is designed to be a self-report questionnaire for students to respond at the end of each course (NIDA, 2012b). It is a three-page questionnaire. The purposes of the evaluation appear at the top of the first page of the evaluation sheet. Evaluators are asked to provide the following information: semester of evaluation, academic year of evaluation, section of evaluation, course code, course title, instructor's name, school, level of degree, and program type (NIDA, 2012b). Students are not asked to provide information that could be used to identify them personally.

The form consists of 25 Likert-type questions, each of which includes a not applicable option. These questions cover three aspects, and there are nine open-ended questions covering the three aspects.

The first aspect covered in the form concerns the effectiveness of the teaching and learning. There are seven Likert-type questions related to the first aspect. The second aspect covered in the form involves the faculty member's personal capability. There are seven Likert-type questions related to the second aspect. The third aspect covered in the form involves the teaching and learning media aspect. There are three Likert-type questions that measure the use of learning media as a whole. There are another eight items that measure the use of E-learning media (National Institute of Development Administration. Personnel Department, 2012a). As per the open-ended section of the form, there is one question that asked about the effectiveness of E-learning. This question, along with other open-ended questions, appeared right after the Likert-scale questions. Other open-ended questions asked for opinions about problems and obstacles, as well as suggestions about E-learning.

Students are required to complete the faculty evaluation form for every course they take. Failing to do so results in 30-day withholding of grades announcement for that particular semester.

\section{METHOD}

According to Sritanyarat (2014), the first implication for future research was to develop and refine empirical indicators of their newly developed theory. This study followed the six steps of Dubin's theory building, as proposed by Sritanyarat (2013). More specifically, the six steps of Dubin's theory building model were taken by adapting Holton and Lowe's (2007) concept in performing Dubin's theory building model from step one to step five Sritanyarat's (2013) research process was presented in the middle column of the following figure. 
This study took on Sritanyarat's (2014) conceptual framework of multidimensional learners' evaluation. Specifically, empirical indicators were developed by the systematic approach suggested by Hinkin (2005).

According to Sritanyarat (2014), there are 25 units included in the framework. Units are put together in groups of learners-related units, instructors-related units, course-related units, and supporting element-related units. The following are the 25 units.
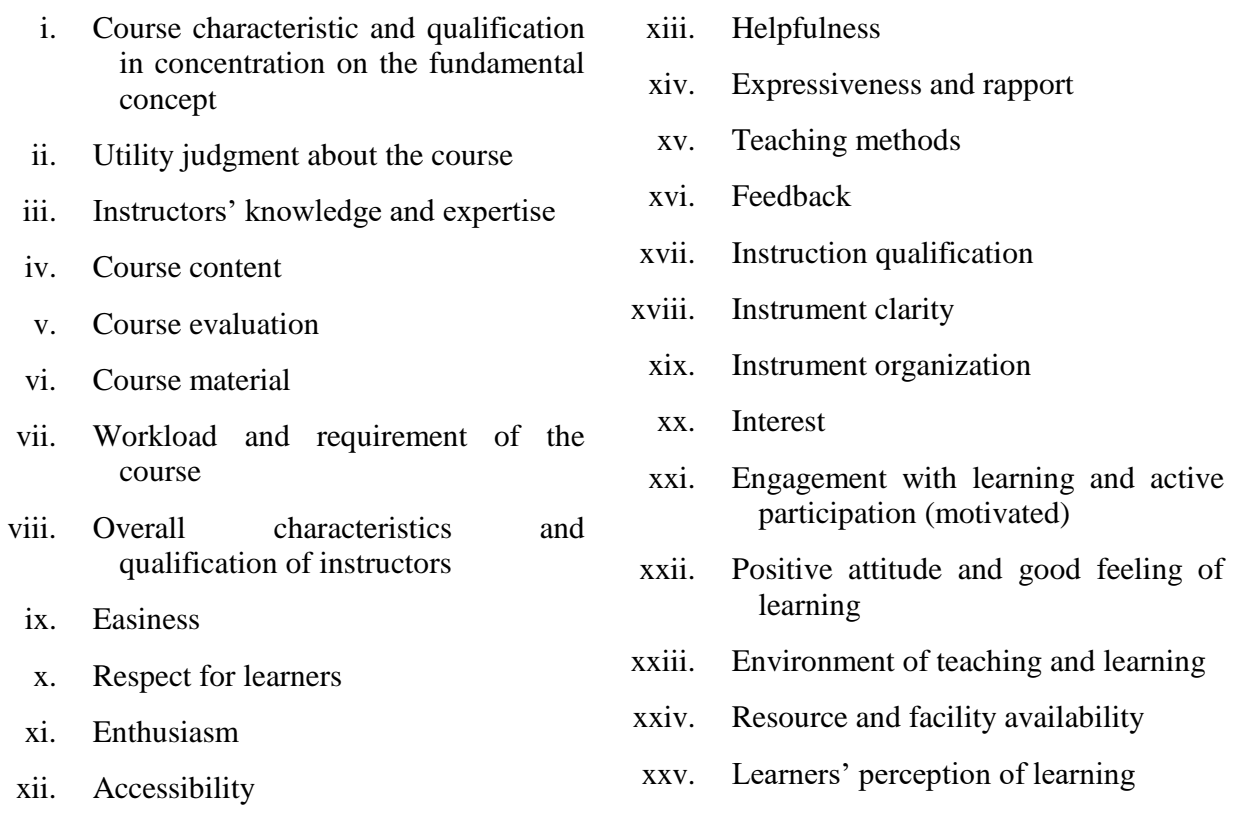

Taking all 25 units, the following was the procedure used for items generation. The following are steps in research method.

\section{Developing empirical indicators}

Item generation, wording, and scaling

To generate items to represent empirical indicators, every unit and its elaboration provided by Sritanyarat (2014) were used to acquire theoretical definitions. Literature reviews were also conducted to develop theoretical definitions for every conceptual dimension and to generate items out of those definitions. There were 46 items initially developed.

Items needed to be initially developed in English as it represented the language for the theoretical conceptual framework and the literature that had been reviewed. Back translation was performed to translate into the Thai language, which was the first language for NIDA students who were the expected survey participants. The back translated version was put together with the English version so that evaluators could choose to perform their evaluation in either languages at will. Likert-type items with a 
five-point scale were selected, since they can increase coefficient alpha reliability (Hinkin, 2005). The term used for the does not apply option was Unable to evaluate.

Content validity assessment

Content validity was assessed by the concept of indexes of item-objective congruence (IOC) to evaluate content validity as mentioned by Turner and Carlson (2003). The recent Standards for Educational and Psychological Testing (2014) indicated that, although validity is considered a unitary concept, there are different forms of evidence. One type of evidence is evidence based on the content. In this case, experts in the field examined parts of the instrument in relationship to the concept being measured.

After analysis of the IOC results, changes were made according to the suggestions from experts, who were stakeholders of teaching and learning in NIDA including instructors, support officers, and students. Items were excluded, collapsed, and modified, and changes were made in verb selection. After this stage of content validity assessment and modification, there were 39 items included in the questionnaire for students to complete.

\section{Testing the empirical indicators}

Target population included all 7,111 students of NIDA (National Institute of Development Administration, 2011b). According to Krejcie and Morgan's (1970) suggestion, for a population of 8,000, 367 respondents are needed. Questionnaires were distributed to students at the end of the second semester of the academic year 2012. After data collection was performed, the item-to-response ratio was 1:25.2778. The total number of respondents was 910 .

The following are reports on respondents' demographic data including type of program in which respondents were enrolled, type of courses respondents were evaluating, and grade point average of respondents. The demographic data shows that respondents from regular programs were lower in percentage (30.66\%) compared to those from executive programs $(66.04 \%)$, which aligns with NIDA's percentage of students from regular programs and executive programs. Type of courses was grouped into three categories: core course $(44.62 \%)$, major course $(33.41 \%)$, and elective course $(21.87 \%)$. The ratio shows a somewhat similar percentage of respondents who were taking core courses and major courses, while those who were taking elective courses showed a somewhat lower number of responses. Respondents' learning performance in the form of grade point average was grouped according to NIDA's grading system. NIDA's grading system is as follow. The maximum grade point is 4.00 , which equals to the grade mark of A. The grade mark of A- refers to 3.70 . B+ refers to 3.30. B refers to 3.00. It was found that most of the respondents had a GPA of 3.30-3.70 (40.44\%). Preliminary factor analysis

Exploratory factor analysis (EFA) with a varimax rotation was used to explore what factors were of the theoretical conceptual framework of multidimensional learners' evaluation using the data from NIDA's students. [A varimax rotation, as one of the most common rotations, results in orthogonal factors that maximize the variance of 
those factors.] The following shows findings about factors that emerged when using the multidimensional learners' evaluation in teaching and learning evaluation at NIDA. This study adopted a minimum loading of .40 , which was considered .10 higher than the minimal level (Hair et al., 1998).

\section{Internal consistency assessment}

Internal consistency reliability was evaluated and reported by using Cronbach's alpha (Price \& Mueller, 1986). This step was performed to allow the tailoring of scales to have the same number of items and still retain adequate domain sampling by carefully examining each item (Hinkin, 2005).

\section{FINDINGS}

After performing the principles and practices in scale development suggested by Hinkin (2005) in developing the empirical indicators, slight changes were made in the items that were retained. One item was not retained as it yielded the factor loading of lower than .40. Two items were excluded, because they were developed to be course related, but the EFA put them in the factor of instructor's teaching skills. However, the five factors from the initial conceptual framework retained: instructor's behaviors and interpersonal skills, learners, instructor's teaching skills, course, and supportive elements. The following table reports the retained factors, units, and the number of items.

Table 1: Retained factors, units (of the 25 units of evaluation), and item components

\begin{tabular}{lll}
\hline Retained Factors & Number of Units & Number of Items \\
\hline Instructor's Behaviors and Interpersonal Skills & 8 & 11 \\
\hline Learners & 5 & 10 \\
\hline Instructor's Teaching Skills & 5 & 7 \\
\hline Course & 4 & 5 \\
\hline Supportive Elements & 1 & 3 \\
\hline Total & 23 & 36 \\
\hline
\end{tabular}

Within the factor of Instructor's Behaviors and Interpersonal Skills the following units appear: knowledge and expertise, overall characteristics and qualifications of work ethics and punctuality, easiness, respect for learners, enthusiasm, accessibility, helpfulness, and expressiveness and rapport. An example of one of the items is the instructor shows open-mindedness to different opinions, and respects different opinions. Within the factor of Learners are the unites: interest, engagement in learning and active participation (motivated), positive attitude and good feeling about learning, environment of teaching and learning, and learners' perception of learning. An example of one of the items is in classes, your classmates are engaged with learning, active participating and interacting with instructor. Within the factor of Instructor's Teaching Skills there are five units: teaching methods, feedback, Instruction qualification, instrument clarity, and instrument organization. An example of an item is the instructor provides feedback to learners. The factor of Course includes these units: course characteristics and qualification in concentration on the fundamental concept, utility judgment about the course, and course content. An example of an item is this course can contribute to the 
preparation for learners' future work. The final factor of Supportive Elements includes one unit: resource and facility availability. An example item is support material and library resources that met with needs for the subject matter, such as internet system, database, computer software, are available and appropriate.

Reliability coefficients were determined for each factor, as recommended by Hinkin (2005). According to Tavakol and Dennick (2011), the minimum acceptable numeric values of Cronbach's alpha ranged from .70 to .95 . A Cronbach's alpha of .961 was found. After performing the reliability coefficient test, one item was excluded, as the correlated item-total correlation of .240 was found. Overall alpha results were higher when the item was deleted. After excluding the item the Cronbach's alpha of .963 was revealed, which could be described as an acceptable internal consistency. The followings are reports on reliability coefficient test obtained by using Cronbach's alpha of each factor considering only items belonging to the particular factors.

Table 2: Reliability coefficient for every individual factor

\begin{tabular}{llllll}
\hline Factor & $\begin{array}{l}\text { Number of } \\
\text { Items }\end{array}$ & $\begin{array}{l}\text { Correlated } \\
\text { Total Correlation }\end{array}$ & $\begin{array}{l}\text { Alpha } \\
\text { Item Deleted }\end{array}$ & $\begin{array}{l}\text { if } \\
\text { Matrix Range }\end{array}$ \\
\hline $\begin{array}{l}\text { Instructor's } \\
\text { and Interpersonal Skills }\end{array}$ & 11 & .936 & $.926-.939$ & $.2725-.7743$ \\
\hline Learners & & 10 & .922 & $.913-.924$ & $.340-.762$ \\
\hline $\begin{array}{l}\text { Instructor's } \\
\text { Skills }\end{array}$ & Teaching & 7 & .937 & $.925-.932$ & $.629-.762$ \\
\hline Course & & 5 & .866 & $.829-.856$ & $.441-.693$ \\
\hline Supportive Elements & 2 & .654 & - & .486 \\
\hline Total & 35 & - & - & - \\
\hline
\end{tabular}

After completing the EFA and internal consistency assessment, five factors, 23 units with 35 items were retained.

\section{DISCUSSION}

\section{Multidimensionality}

This study proposes the use of multidimensional learners' evaluation tool for higher education in Thailand. The proposed concept aligns with what was suggested by Morgan and Casper (2000): that a multi-dimensional approach of reaction evaluation needed to be well designed to ensure the reliability of learners' evaluation. The final conceptual framework includes five factors, namely course, supportive element, instructor's teaching skills, instructor's behaviors and interpersonal skills, and learners. Those five factors could be regarded as four dimensions of teaching and learning evaluation, namely, course-related, instructor-related, learners-related, and supportive element-related. There are two factors that fall in the dimension of instructor-related: instructor's teaching skills, and instructor's behaviors and interpersonal skills.

Discussion pertaining to the existing literature and NIDA Faculty Evaluation Form 
This study supports Sritanyarat's (2014) proposition that teaching and learning evaluation is multidimensional by separating issues of course-related, learner-related, and supporting element-related from those of instructor-related issues. According to the results, the focus of teaching and learning evaluation is not only on instructors, but also on learners, as well as course and the supportive environment since courses and learning environments are not designed solely by instructors. The units, which were the basic building blocks represent what the researcher tried to make sense of (Dubin, 1983; Lynham, 2002), obtained from the systematic literature review, items of NIDA's Faculty Evaluation Form (FEF), and units proposed in the results of this study are compared and discussed.

\section{Discussion of the confirmed units}

The NIDA FEF includes six units, all of which are instructor-related: instructors' qualification of instruction, instrument organization of instructors, instrument clarity of instructors, overall instructors' characteristics and qualification, accessibility of instructors, and teaching methods of instructors. The present study confirms these units within the factors identified in the factor analysis: instructor's behaviors and interpersonal skills, and instructor's teaching skills. All six units are what instructors can perform to ensure the quality of teaching and learning.

In addition to NIDA'S FEF, the OHEC in Thailand has identified indicators of higher education quality. One indicator focuses on system and mechanism of teaching and learning administration (National Institute of Development Administration, 2011a) and this suggests that every program should have a learning system and mechanism that encourage learners-centered concept. Moreover, every program must provide learning plan for each course before the semester begins. Each course of the program should be designed to integrate body of knowledge from the field of practice. Learning should be both classroom-based and non-classroom approach. Research must be incorporated in every course. Learners' evaluation results must be reported. The minimum passing score is 3.51 out of 5.00. Moreover, every course must be developed according to the evaluation results (National Institute of Development Administration, 2011a).

NIDA's current teaching and learning evaluation incorporates the above units and uses them as points for development. Thus, it is reasonable and important for the results of the present study to agree with both the NIDA FEF and the OHEC's number 2.6 quality indicators.

\section{Discussion of factors and units emerging from the study}

Three factors emerged that go beyond NIDAs FEF, specifically course, learners, and supportive environment. Within each of the factors appear specific units. Three courserelated units emerged: overall course quality and characteristics, course content, and utility judgment. There are five learner-related units: interest in learning of learners, environment for teaching and learning, learners' positive attitude and affect or satisfaction, learners' engagement with learning and active participation, as well as learners' perceptions of learning. Finally, two supportive units emerged: resources availability, and technology availability. 
The course-related, learner-related, and supportive element-related factors and units appeared in this study but are not included in NIDA's FEF. Such results probably appeared because NIDA's FEF puts its focus on only e-learning as part of teaching methods unit.

As part of the instructor behaviors and interpersonal skill factor units there are seven instructor-related units. It should be noted that NIDA's current evaluation only focuses on instructor behaviors and does not consider personal or personality characteristics. Nevertheless, some of the units listed below that emerged from the current study suggest that both behaviors and characteristics are of importance.

i. Helpfulness of instructors emerged from the results of this study. It could be discussed that this emerged as Thai learners are teacher-centered (Johansen and Gopalakrishna, 2006; Komin, 1990). It is likely that Thai students would appreciate instructors' being helpful.

ii. Instructor's expressiveness and rapport was revealed by this study. It refers to instructors' consideration for learners, expressiveness and interaction with learners, and ability to develop rapport with learners. Thai students' value of an appreciative orientation, as suggested by Komin (1990), would suggest that an instructor being expressive and cordial is of concern.

iii. Enthusiasm of instructors was also revealed by this study. It refers to the instructor being genuinely interested in teaching (Zhao \& Gallant, 2012). This does not solely relate to the instructor's action, but also refers to some personality characteristics of the instructor.

iv. Feedback providing is a behavioral unit revealed by this study. The current NIDA's FEF includes an item concerning the instructor being able to advise students via appropriate channels. This item could be considered as partially related to the element of feedback providing.

v. Respect for learners by instructors was found from the results but is not included in NIDA's current evaluation form. It is possible that this emerged due to the data collection from students and officers from graduate schools. NIDA's current evaluation was designed without input from students and officers from graduate schools, who work closely to students. This subject might come to an interest because of Thai's value system. According to Komin (1990), Thai people are ego oriented and are not able to tolerate ego violations or offenses. Even when they are taking the role of student; they prefer to earn respect from instructors, especially, when they consider themselves as adults and in higher education system.

vi. Easiness of instructors emerged from the results of this study. Easiness which is emerging here does not refer to instructors as easy graders. It refers to whether instructors are easy to talk to, whether they are kind and supportive, as well as whether they provide a positive relationship with learners. It is highly possible that it emerged 
due to the input of students and graduate school officers. It may be of concern because of Thai's value system as well. Thai's prefer to maintain smooth relationships (Komin, 1990). Consequently, instructors who are easy to approach would be more preferable in order to have a qualified learning experience for learners.

vii. The instructor's knowledge and intellect are characteristic units proposed by this study. Some may question whether learners are competent to evaluate their instructor's knowledge. However, it is obviously a concern and expectation of Thai's value system. Instructors are valued as superiors, as Thai culture values good grades and high levels of education, as well as a focus on labels in social relations (Komin, 1990). When instructors are considered superior, expectations are placed on them to exhibit their knowledge.

Discussion of the units found in NIDA's FEF which is not confirmed by the results of this study

There is one unit which was found only in FEF which was not supported by the results of this study: the use of proper research results or academic services in the course content. This unique item could be derived from the objective of NIDA as being a research university; therefore, it is likely that NIDA's FEF includes this unit. It may be that learners or students do not view NIDA as being a research university. Research may not be a major concern of students, as most of them are in the field of practice.

Additionally, there are four units which cover many items of FEF, namely instrument organization of instructors, instrument clarity of instructors, overall instructors' characteristics and qualification of work ethics, open-mindedness, and punctuality, and teaching methods of instructors. They are basically evaluated altogether. However, this study suggests that they should be evaluated separately.

\section{LIMITATIONS}

This study takes on the conceptual framework proposed by Sritanyarat (2014) to develop empirical indicators to complete the research process suggested by Sritanyarat (2013). It is possible that there are more units and laws of interaction that have not been uncovered yet.

Three groups of stakeholders in NIDA - students, instructors, and officers or staff -were involved in this study. It is possible that different groups of stakeholders, such as employers, higher levels of administration, or government officials, could provide different aspects on higher education evaluation (Green, 1994; Tam, 2001). To delimit, this study can be replicated and extended by inclusion of more groups of stakeholders in the qualitative data collection. Employers could be involved as users of graduates from NIDA. Top management of NIDA and alumni could be included as another group of stakeholders.

The data collection about teaching and learning evaluation is considered sensitive. Data regarding the school names, program names, instructors' names, and other information that could be used to identify the instructors of the courses were not allowed to be collected. Therefore, analysis using the previously-mentioned data, such as comparative 
analysis among the different schools, could not be performed. Moreover, different schools had different preferences in assigning groups of respondents and the researcher needed to comply with the schools' preference in collecting the data. Future studies may be undertaken using similar groups but from different schools or higher education institutions.

\section{RECOMMENDATIONS FOR FUTURE RESEARCH}

Firstly, the development and then testing of the hypotheses are needed to complete Dubin's model. The step of developing a hypothesis represents an establishment of the link between the theoretical framework and the real world, by translating some of the propositions of the theoretical framework to testable hypotheses (Lynham, 2002). One possible hypothesis might be that the instructor characteristics have a direct effect on all other dimensions.

Secondly, empirical research studies are needed to validate the conceptual framework in the real work context. This step involves the testing of the theory through empirical research. The results of this study can be adopted as variables in some of the future empirical studies.

Thirdly, replication of this study could be performed in other higher education institutions in Thailand for the purpose of further generalization. There is a possibility that different contexts of higher education, even those in Thailand, hold different characteristics from NIDA. Furthermore, beyond Thailand, replication of the study could be undertaken in higher education institutions in other countries and cultures.

In order to complete Dubin's theory for making method, further research needs to be done. The development and testing of the hypotheses would complete the theoretical conceptual framework and would make a greater contribution to both academia and practice.

\section{IMPLICATIONS FOR PRACTICE}

This study proposed and developed an integrated framework and questionnaire which can be considered as a tool for multidimensional learners' evaluation to assess the quality of teaching and learning in higher education. The emerging factors and units of the framework can be taken as issues of concern in evaluating quality of teaching and learning in higher education in Thailand, as well as other more general settings.

The results of this study can be utilized in human resource management mechanism of NIDA, as well as other higher education institutions in Thailand. Learners' evaluation is undertaken for the purpose of human resource management of NIDA faculty and instructors (National Institute of Development Administration. Personnel Department, 2012a). The questionnaire obtained from this study can be adopted for use in teaching and learning evaluation as it was developed with indigenous data and context. For other higher education institutions in Thailand, it is important to verify the questionnaire within the specific context with specific stakeholders or an expert panel before 
performing the data collection. However, to use the questionnaire, it is recommended to consider the length of the questionnaire, since it can affect its' reliability and validity. It is recommended that mechanism and system of evaluation should be carefully designed to promote interest of learners in completing the questionnaire, or to compel learners to complete the questionnaire.

\section{REFERENCES}

American Educational Research Association, American Psychological Association, National Council on Measurement in Education. (2014). Standards for educational and psychological testing. Washington, DC: American Educational Research Association.

Dubin, R. (1969). Theory building. New York: Free Press.

Dubin, R. (1983). Theory building in applied areas. In M. Dunnette (Ed.), Handbook of industrial and organizational psychology (pp. 17-39). New York, NY: John Wiley.

Green, D. (1994). What is quality in higher education?: Concept, practice and policies. In D. Green (Ed.), What is quality in higher education? (pp. 3-19). PA: Taylor \& Francis.

Hair, J. F., Anderson, R. E., Tatham, R. L., \& Black, W. C. (1998). Multivariate data analysis $\left(5^{\text {th }}\right.$ ed.). Upper Saddle River, NJ: Prentice Hall.

Hendry, G. D., \& Dean, S. J. (2002). Accountability, evaluation of teaching and expertise in higher education. International Journal of Academic Development, 7(1), 75-82. doi: 10.1080/13601440210156493.

Hinkin, T. R. (2005). Scale development principles and practices, In R. A. Swanson, \& E. F. Holton III (Eds.), Research in Organizations (pp. 161-179). San Francisco, CA: BarrettKoehler.

Holton III, E. F., \& Lowe, J. S. (2007). Toward a general research process for using Dubin's theory building model. Human Resource Development Review, 6(3), 297-320. doi: $10.1177 / 1534484307304219$.

Johansen, B. C. P., \& Gopalakrishna, D. (2006). A Buddhist view of adult learning in the workplace. Advance in Developing Human Resources, 8(3), 337- 345. doi: $10.1177 / 1523422306288426$.

Komin, S. (1990). The psychology of the Thai People: Values and behavioral patterns. Bangkok, Thailand: Research Center, National Institute of Development Administration.

Krejcie, R. V., \& Morgan, D. W. (1970). Determining sample size for research activities, Educational and Psychological Measurement, 30, 607-610.

Lowe, J. S., \& Holton, E. F. (2005). A theory of effective computer-based instruction for adults. Human Resource Development Review, 4(2), 159-188. doi: $10.1177 / 1534484305276301$.

Lynham. S. A. 2002. Quantitative research and theory building: Dubin's method. Advance in Developing Human Resources, 4(3), 242-276. doi: 10.1177/15222302004003003.

Morgan, R. B., \& Casper, W. J. (2000). Examining the factor structure of participant reactions to training: a multidimensional approach. Human Resource Development Quarterly, 11(3), 301- 307. 
National Institute of Development Administration. (2011a). คู่มือการประกันคุณภาพการศึกษา สถาบันบัณฑิตพัฒนบริหารศาสตร์ ประจำปีการศึกษา ๒๕๕๕ [The education quality manual of the National Institute of Development Administration for academic year 2011], Bangkok, Thailand.

National Institute of Development Administration. (2011b). รายงานจำนวนนิสิต/นักศึกษาทั้งหมด ภาคการศึกษา ๑/๒๕๕๕ จำแนกตามคณะ สาขาวิชา ระดับการศึกษาและเพศ [Total student report of semester 1/2011 by schools, majors, degree, and gender], Bangkok, Thailand.

National Institute of Development Administration. Personnel Department. (2012a). ประกาศหลักเกณฑ์และแนวปฏิบัติในการประเมินผลการเรียนการสอนของสถาบัน

[Announcement of Principles and Practices of Teaching and Learning Evaluation of the Institute], Bangkok, Thailand.

National Institute of Development Administration. (2012b). แบบประเมินผลการเรียนการสอนของอาจารย์ [Faculty Evaluation Form], Bangkok, Thailand.

Office of the Higher Education Commission. (2007). กรอบแผนอุดมศึกษาระยะยาว ๑๕ ปี ฉบับที่ ๒ (๒๕๕๑-๒๕๕๕) [Long-Term Higher Education Plan for 15 Years $2^{\text {nd }}$ Issue (20082022)], Bangkok, Thailand.

Price, J. L., \& Mueller, C. W. (1986). Handbook of organizational measurement. Cambridge, MA: Ballinger.

Shevlin, M., Banyard, P., Davies, M., \& Griffiths, M. (2000). The validity of student evaluation of teaching in higher education: Love me, love my lectures? Assessment \& Evaluation in Higher Education, 25(4), 397-405. doi: 10.1080/713611436.

Sritanyarat, D. (2013). Development of theoretical-based multidimensional learners' evaluation in Thai higher education: A case study of the National Institute of Development Administration (Unpublished doctoral dissertation). National Institute of Development Administration, Bangkok, Thailand.

Sritanyarat, D. (2014). Development of theoretical-based multidimensional learners' evaluation in Thai higher education: A case study of the university in graduate level. NIDA Development Journal, 54(4), 17-56.

Tam, M. (2001). Measuring quality and performance in higher education, Quality in Higher Education, 7(1), 47-54, doi: 10.1080/13538320120045076.

Tavakol, M., \& Dennick, R. 2011. Making sense of Cronbach's alpha, International Journal of Medical Education, 2, 53-55. doi: 10.5116/ijme.4dfb.8dfd

Turner, R. C., \& Carlson, L. (2003). Indexes of item-objective congruence for multidimensional items, International Journal of Testing, 3(2), 163-171. doi: 10.1207/S15327574IJT0302_5.

Wachtel, H. K. (1998) Student evaluation of college teaching effectiveness: A brief review, Assessment \& Evaluation in Higher Education, 23(2), 191-212. doi: $10.1080 / 0260293980230207$. 
Yamnill, S. (2001). Factors affecting transfer of training in Thailand (Unpublished doctoral dissertation). University of Minnesota, Minneapolis, MN.

Zhao, J., \& Gallant, D. J. (2012). Student evaluation of instruction in higher education: exploring issues of validity and reliability, Assessment \& Evaluation in Higher Education, 37(2), 227-235. doi: 10.1080/02602938.2010.523819.

\section{Turkish Abstract}

Thai Yükseköğretimi’nde Ampirik Değerlendirme Göstergeleri: Teori-Temelli Çok Boyutlu Öğrenci Değerlendirmesi

Bu çalışma Tayland'da yükseköğretim kurumlarının gelişimi ve insan kaynaklarının yönetimi için değerlendirme kriteri olarak kullanılmak ve yükseköğretimde öğretmen ve öğrenmenin kalitesini değerlendirmek için geçerlenebilecek ve uyarlanabilecek ampirik göstergeler sunmayı amaçlamaktadır. Bu çalışmanın ana amacı Ulusal Gelişim Yönetimi Kurumunu bir örnek olay olarak alarak Thai yükseköğretiminde teori-temelli çok boyutlu öğrenci değerlendirmesinin ampirik göstergelerini geliştirmektir. Bu çalışmanın yöntemi Dubin Teori Geliştirme Modeline dayanılarak geliştirilmiştir. Yeni geliştirilen kavramın temel yapı taşları olan üniteler sistematik literatür taramasından, nicel veri toplamadan ve Likert ölçekli anketlerden elde edilen veri üçlemesi yoluyla nitel ve nicel olarak geliştirilmiştir. Kavramsal çerçeveyi değerlendirmek için Patterson'un (Holton and Lowe, 2007 içinde) ölçütü kullanılmıştır. Veri toplama aracı olarak anket kullanılmıştır. Ampirik göstergeleri geliştirmek için toplanan veriyi analiz etmede açımlayıcı faktör analizi ve Cronbach Alfa analizi kullanılmıştır.

Anahtar Kelimeler: Öğrencinin değerlendirmesi, yükseköğretim, Tayland, Dubin, teori geliştirme

\section{French Abstract}

Indicateurs d'Évaluation Empiriques dans Enseignement Supérieur Thaï:l'Évaluation d'Apprenants Multidimensionnels Ä Base de Théorie

Cette étude a proposé les indicateurs empiriques qui peuvent être validés et adoptés dans des institutions d'enseignement supérieur pour évaluer la qualité d'enseignement et l'apprentissage et servir de critères d'évaluation pour la gestion des ressources humaines et le développement d'institutions plus hautes en Thaïlande. Le but principal de cette étude était de développer les indicateurs empiriques d'une évaluation des apprenants multidimensionnels théoriquement basés dans l'enseignement supérieur thaï adoptant l'Institut national d'Administration de Développement comme une étude de cas. La méthode de recherche de cette étude a été développée basée sur la Théorie de Dubin Construisant le Modèle. Les unités, qui sont les composantes de base de concept nouvellement développé, ont été développées qualitativement et quantitativement en triangulant des données de l'examen systématique de littérature, la collecte de données qualitative et l'enquête de Likert-échelle. Patterson (dans Holton et Lowe, 2007) le critère a été utilisé pour évaluer le cadre conceptuel. Le questionnaire a été utilisé comme un outil pour la collecte de données. L'analyse de facteur exploratoire et l'analyse alpha de Cronbach ont été utilisées pour analyser des données rassemblées pour développer des indicateurs empiriques.

Mots Clés: l'évaluation d'apprenants, enseignement supérieur, la Thaïlande, Dubin, construction de théorie

\footnotetext{
Arabic Abstract

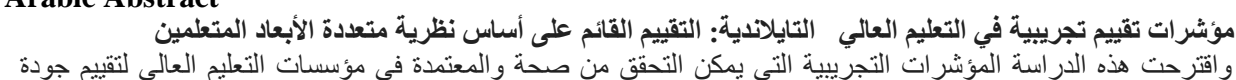




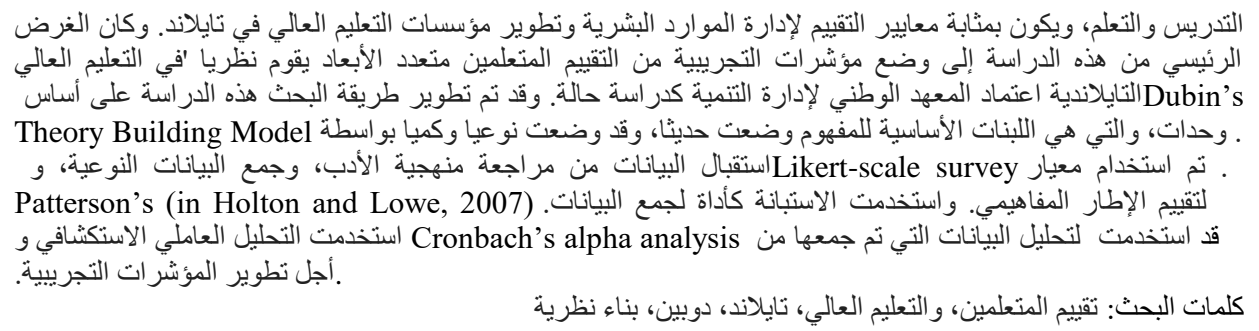

\section{German Abstract}

Empirische Bewertungsindikatoren im Thailändisch Höhere Bildung: Theoriebasierte Bewertung der Multidimensionalen Lerners

Diese Studie vorgeschlagene empirische Indikatoren, die in Hochschuleinrichtungen validiert und angenommen werden kann, Qualität der Lehre und des Lernens zu bewerten und als Bewertungskriterien für Personalmanagement und Entwicklung der höheren Institutionen in Thailand zu dienen. Der Hauptzweck dieser Studie war es, empirische Indikatoren für die Bewertung eines theoretisch-basierten multidimensionalen Lernenden in Thai höheren Bildung zu entwickeln. Wir nahm die National Institute of Development Administration als Fallstudie. Forschungsmethode dieser Studie wurde auf Basis von Dubin Theorie Gebäudemodell entwickelt. Einheiten, die neu entwickelte Konzept Grundbausteine sind, wurden qualitativ und quantitativ entwickelt von Daten aus der systematischen Literaturrecherche, die qualitative Erhebung von Daten und der Likert angelegte Umfrage Triangulation. Patterson (in Holton und Lowe, 2007) Kriterium wurde verwendet, um den konzeptionellen Rahmen zu bewerten. Fragebogen wurde als ein Werkzeug zur Datenerfassung benutzt. Explorative Faktorenanalyse und Cronbachs AlphaAnalyse wurden eingesetzt, um die gesammelten Daten analysieren, um empirische Indikatoren zu entwickeln.

Schlüsselwörter: bewertung der lernenden, hochschulbildung, Thailand, dubin, theoriebildung

\section{Malaysian Abstract}

Penilaian Empirikal Petunjuk Pengajian Tinggi di Thailand: Teori Berasaskan Penilaian Multidimensional Pelajar

Kajian ini mencadangkan petunjuk empirikal yang boleh disahkan dan diterima pakai di institusi pengajian tinggi untuk menilai kualiti pengajaran dan pembelajaran, dan untuk berkhidmat sebagai kriteria penilaian bagi pengurusan sumber manusia dan pembangunan institusi pengajian tinggi di Thai. Tujuan utama kajian ini adalah untuk membangunkan petunjuk empirikal berasaskan teori pelbagai dimensi pelajar dalam pendidikan tinggi Thai dengan menggunakan Institut Tadbiran Pembangunan sebagai kajian kes. Kaedah penyelidikan kajian ini telah dibangunkan berdasarkan Dubin's Theory Building Model. Unit, merupakan blok binaan asas konsep baru yang dibangunkan, telah dibangunkan secara kualitatif dan kuantitatif melalui triangulasi data daripada kajian literatur yang bersistematik, pengumpulan data secara kualitatif dan tinjauan menggunakan skala Likert. Patterson (dalam Holton \& Lowe 2007) kriteria digunakan untuk menilai rangka kerja konseptual. Soal selidik digunakan sebagai alat untuk pengumpulan data. Analisis faktor penerokaan dan analisis alpha Cronbach telah digunakan untuk menganalisis data yang dikumpulkan untuk membangunkan petunjuk empirikal.

Kata Kunci: penilaian pelajar, pendidikan tinggi, Thailand, Dubin, theory building 